\title{
Application of Remote Sensing \& GIS in Crop Information System - a case study of Paddy monitoring in Jamalpur Block
}

\author{
Santanu Pani ${ }^{1}$, Dr. Abhisek Chakrabarty ${ }^{2}$, Dr. Sandhya Bhadury ${ }^{3}$ \\ ${ }^{(1)}$ Research Scholar, Dept. of Remote Sensing \& GIS, Vidyasagar University, West Bengal, India

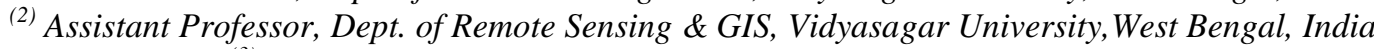 \\ (3) Former Deputy Director, NATMO, Kolkata, West Bengal, India
}

\begin{abstract}
This study focused on the application of Remote Sensing \& Geographic Information System in Development of Crop Information System (CIS) for sustainable rice production in Jamalpur block which is located $\left(23^{\circ} 04^{\prime} \mathrm{N}, 87^{\circ} 59^{\prime} \mathrm{E}\right.$ \& $\left.23^{\circ} 07^{\prime} \mathrm{N}, 87^{\circ} 98^{\prime} \mathrm{E}\right)$ in Burdwan district of West Bengal, India. There rice fields were identified through Remote Sensing (RS) techniques. Aus, Aman and Boro, this three types of paddy (rice) distribution were shown using Landsat TM satellite data. The secondary data were collected from the Assistant Director's office of Agriculture, Jamalpur block. The cultivated area of different types of rice is calculated from each Gram Panchayet. The both data of rice area one which has been calculated by Remote Sensing method and another one which has been collected from ADA office are compared. Field data is used to generate the variation curve of different types of rice production in the block. It is also shown the gradually changing of rice cultivated area in this block. Finally, it is observed that all the geographic queries carried out in this research are as a result of the available dataset. So that, the decision making bodies can access to information on rice growth and management in the study area.
\end{abstract}

Keywords: Remote Sensing, Spatial distribution, Rice Information System

\section{Introduction}

Burdwan District of West Bengal state assumes a very important role in the overall agricultural production and industrial activities. Jamalpur block of Burdwan is one of the high yielding rice producing area in Burdwan. Rice is the single produce, around which agricultural activities of the district rotates ${ }^{(6)}$. If Burdwan district is known as "The Rice-bowl of West Bengal", then Jamalpur is truly called the "Greenery of Burdwan".

\section{Background of the study}

Rice is most important in Jamalpur area for several reasons. The trend for the production and consumption of rice is growing faster than any other food staples. It is a major contributor to internal and sub-regional trade. Rice is also the staple for most of the peoples in the Jamalpur block which is divided into 13 gram panchayets. The river Damodar is flowing in the east part of the block. Most of the rice cultivated lands are there. Farmers find rice more adaptable than a high input staple like wheat, potato, musur, maskalai, khesari, til and others (when there is declining soil fertility because of the huge array of varieties they can switch over to every few years) ${ }^{(1)}$. Since it is becoming a staple crop, farmers seem to be willing to grow it all the time ignoring constraints they are facing.

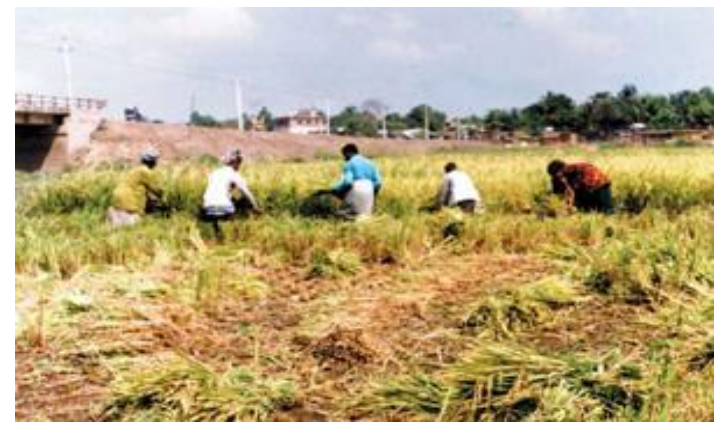

Fig-1: Harvesting of Aman paddy

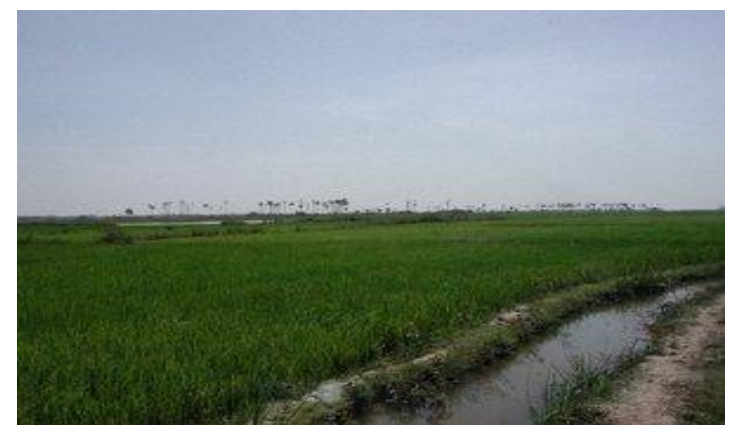

Fig-2: One of the Aman cultivated lands, Jamalpur

Referring to the use of agricultural resources, geospatial information is an effective tool for gathering related spatial data that are capable of identifying a specific crop area in order to reduce problems being faced in 
food production in Jamalpur area. It may provide adequate crop information for proper planning and decision making.

\section{Study Area}

Jamalpur is located at $23^{\circ} 04^{\prime} \mathrm{N}, 87^{\circ} 59^{\prime} \mathrm{E}$ and $23^{\circ} 07^{\prime} \mathrm{N}, 87^{\circ} 98^{\prime} \mathrm{E}$. It has an average elevation of $24 \mathrm{~m}$ (79 ft). The total area of Jamalpur block is 267.88 square kilometers. ${ }^{(6)}$

The Khandaghosh-Jamalpur-Raina area lies on the alluvial plains between the Damodar river on its south-eastern side. Maximum temperature during summer is $44^{0} \mathrm{C}$; minimum temperature during the winter is $5^{0}$ $\mathrm{C}$, Average rainfall $1408 \mathrm{~mm}$. The soils of that area are sandy, well drained and slightly acidic in nature. Water holding capacity of this soil increases with depth as well as with the increase of clay portions. These formed of alluvium brought down by the Damodar river. ${ }^{(6)}$

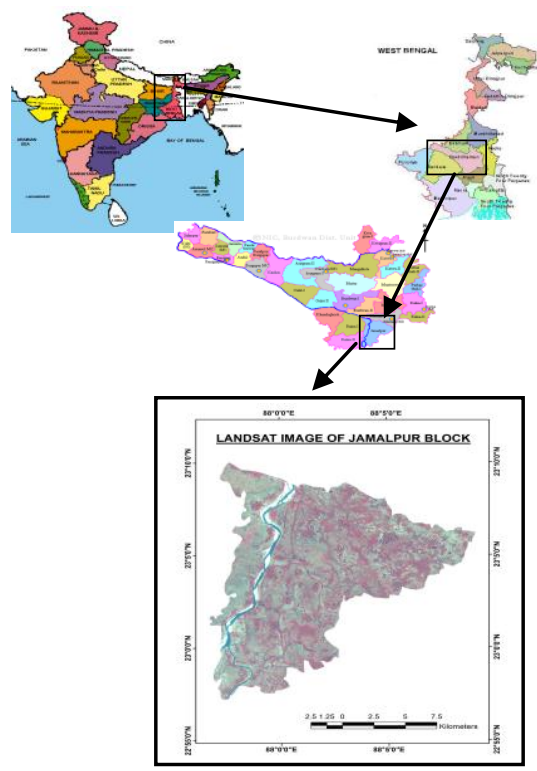

Fig-3: Location Map

IV. Software Used

ERDAS IMAGINE 9.0, ARC GIS-9.3

\section{Methodology:}

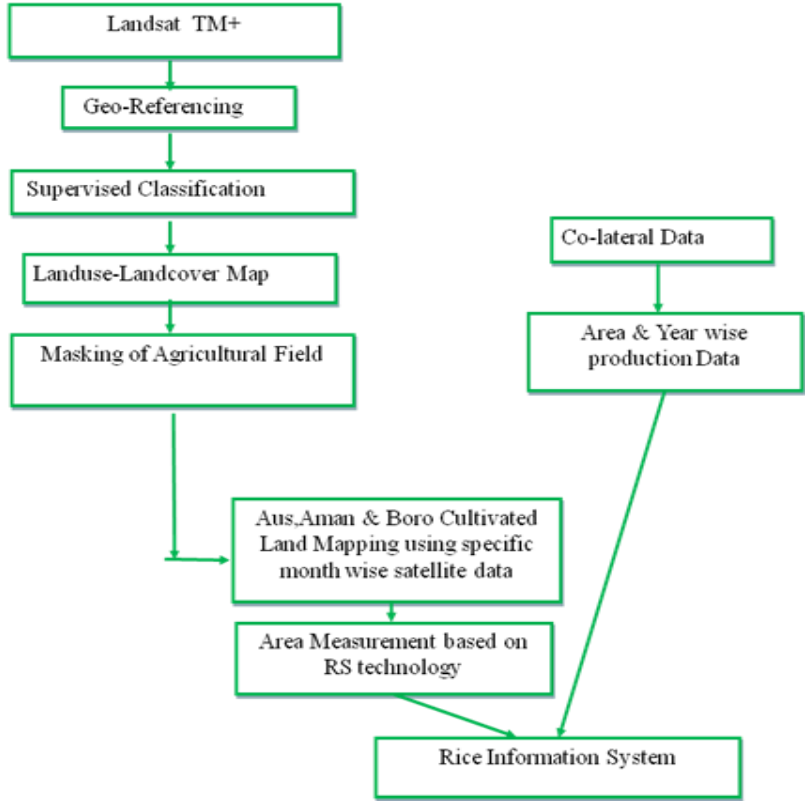

Fig-4: Methodology Flow chart 


\section{STEP OF WORK:}

After collecting the satellite data which had been already geo-referenced, to prepare the landuse map of the Jamalpur area is based on supervised classification. Use of landuse map is to show the agricultural fields of that area. The supervised classification technique has been applied in ERDAS Imagine 9.0 environment. Simply six classes derived from that image, mainly agricultural land, vegetative land, Water logged area, Flood prone area, Water bodies and Built-up land are shown.

The specific agricultural land derived from the masking of agricultural land of their different seasons. The specific month-wise satellite data are required to generate the map of different types of rice distribution. Cultivation time of Aman paddy is in the month of December to February. So, to show the Aman distribution map, the January satellite image is needed. Likewise, Boro and Aus paddy distribution map are shown with the help of April and July image. Basically the entire block of Jamalpur is a 'single crop area'. So, in the time of rice cultivating season there is no other crop cultivation. It is easy to identify after it has been processed with NIR band of Landsat TM data

The secondary data has been collected from the ADA office of Jamalpur. These data obtained to show the production curve of different types of rice and the change of rice cultivated area in the last five years. The GPS point was taken in rice area of Jamalpur and put it into the image. Lastly, we have calculated rice crop area from each gram panchayets and comparing the area data which are calculated from RS method with the field collection data.

\section{Result And Disscussion}

Rice is the most important crop of that block. The Rice grown with its numerous varieties can broadly be grouped under the three primary classes distinguished from one another by distinct characteristics and those are: The Aus or autumn, the Aman or winter and the Boro or the summer rice. Paddy covers maximum of gross cropped area of Jamalpur.

There are mainly seven classes are shown, Agricultural land, Vegetative land, Sandy area, Water body, Built-up land, Flood prone area and Water-logged area. Damodar and Darkeswar, the two rivers are the main water portion of that area. The water-logged area is the storage water for agricultural usage. The flood prone area is already flood affected and potentially flood affective area. The main purpose to generate the land use and land cover map is to show how much agricultural land is there than any other land use \& land cover features. Basically the Jamalpur block area is the one crop land area. So in agricultural land there is mainly ricecultivated-area among any other food crops.

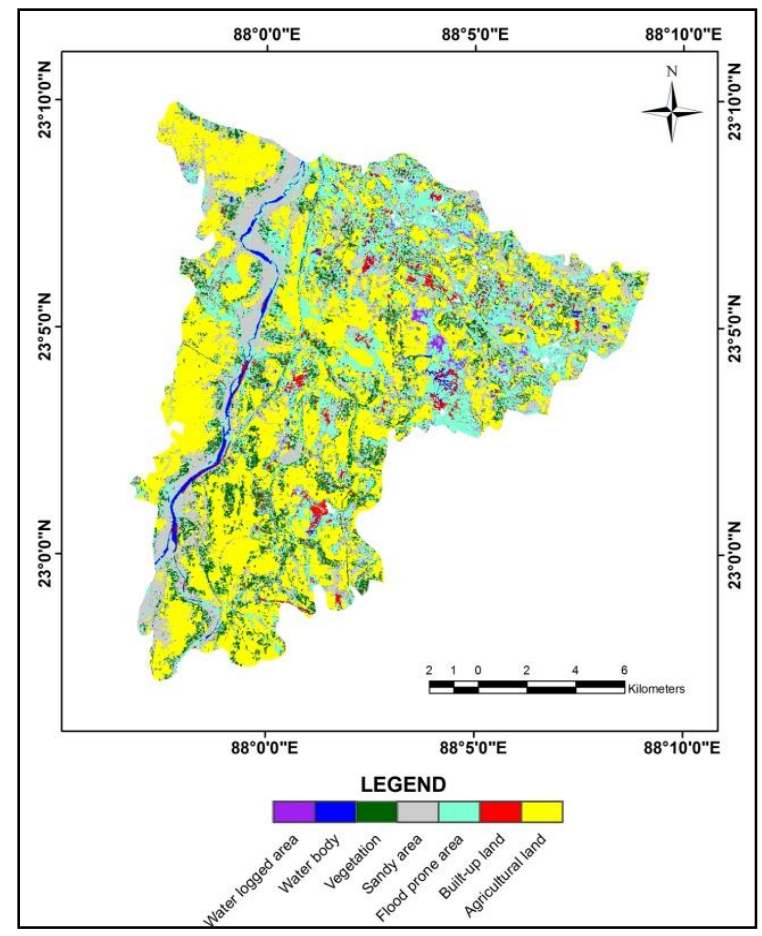

Fig-5: Land use and Land cover map of Jamalpur Block 
TABLE OF RICE CALANDER ${ }^{(2)}$

\begin{tabular}{|c|c|}
\hline RICE TYPES & CALTIVATIVE SEASON \\
\hline AUS & July - August \\
\hline AMAN & Generally December - January \\
\hline BORO & March - May \\
\hline
\end{tabular}

According to the rice calendar Aus paddy is generally cultivated within December to January. So January 2010 Landsat TM satellite data is used to extract the Aman paddy fields of Jamalpur. The whole agricultural land is covered by the Aman field cultivated within December to January. Basically the Aman harvesting season is from last January to middle of February. But exactly Aman paddy is cultivated throughout the year. Here, the both side of river Damodar is the maximum cultivated land of Aman. Out of 13 gram panchayets(GP), Ajharpur has the top rank of aman paddy cultivated land. According to the Remote Sensing technique there is 1293.00

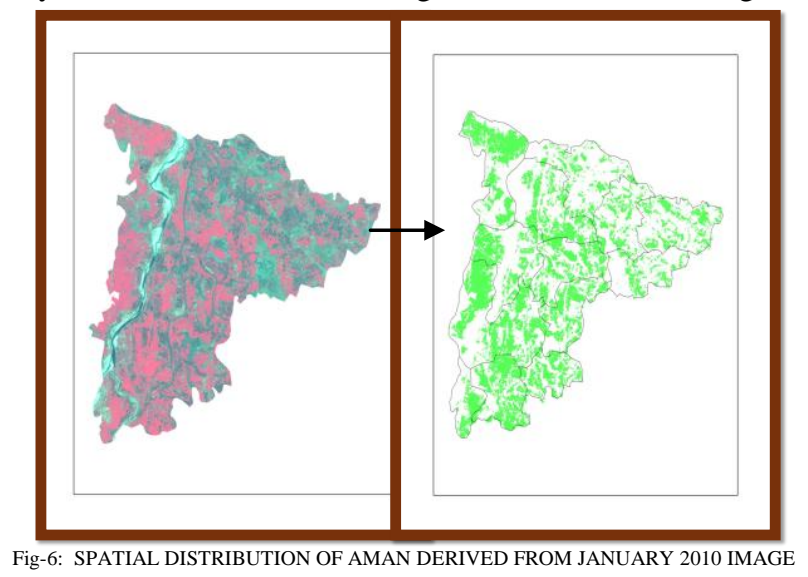

hector are covered by Aman cultivated land. But according to the data from the ADA office, there is 1081 hector Aman cultivated land. Abujhati-I has the lowest cultivated land according to both RS method and field collection data. Total aman cultivated land in the block is 11842.09 hector in the year 2010. There is no such huge difference between RS technique \& field collected data.

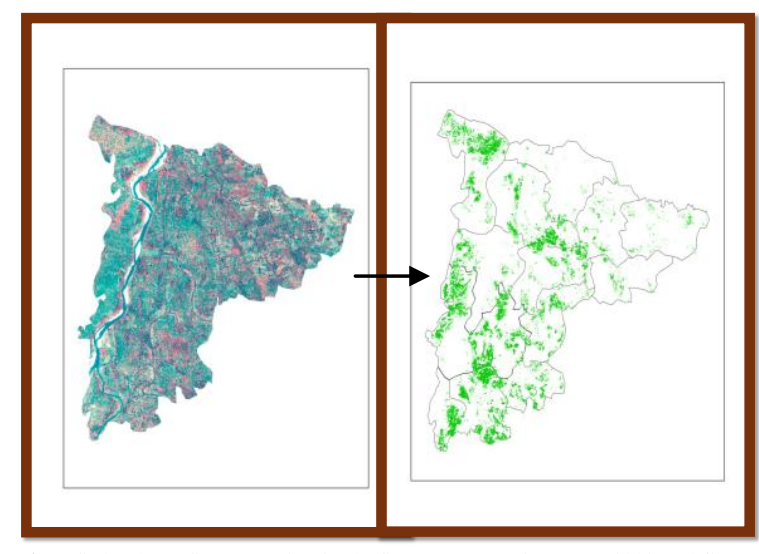

Fig-7: SPATIAL DISTRIBUTION OF AUS DERIVED FROM JULY 2010 IMAGE

This spatial distribution is for another type of rice and that is Aus. Aus paddy cultivated time is from July to August. August is the harvesting season of Aman paddy. So, to extract the Aus area, the July 2010 landsat TM image is used. Generally it is cultivated throughout the year. So, the spatial distribution of Aus is lower than the Aus paddy. In remote sensing and GIS techniques help to extract the spatial distribution of Aus paddy and measure the cultivated area of each gram panchayets as well as the whole block. Here, the highest aus cultivated area in 2010 is covered by Ajharpur (913.19 hector) gram panchayet and lowest Aus cultivated land in 2010 is covered by Jougram GP (341.84) according to RS method. But the ADA office data says that Ajharpur has the second highest cultivated land (907 hector) and lowest cultivated Aus land is in Berugram (404 hector). There are little bit of difference between the data collected from field survey and RS method. Total 
cultivated area of Aus paddy of the block is 8100 hector which has been collected from ADA office. In RS technique the total Aus cultivated area 8010 is hector.

The Boro paddy cultivated time is from March to May. Here, the spatial distribution of Boro paddy cultivated land in 2010 is shown. The Boro distribution is also shown by using the April 2010 Landsat TM satellite data. In 2010 Boro cultivation was much lower than Aus and Aman. Comparing the area data which are calculated from RS method with the field collection data, there are some differences that is one of the limitations of Remote Sensing technology. Chakdighi gram panchayet has the highest Boro cultivated land (61.23 hector) in 2010 according to RS method. As per field collected data Chakdighi gram panchayet has the second highest boro cultivated land (53 hector) and Jaragram has the highest Boro cultivated land (59 hector).

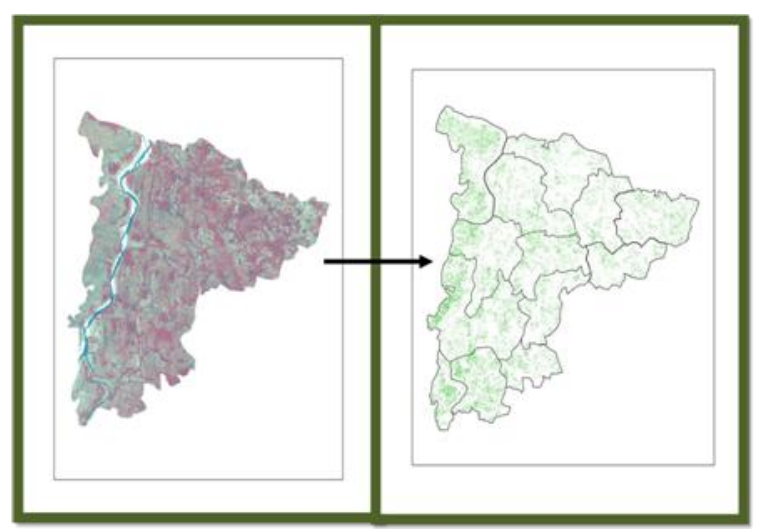

Fig-8: SPATIAL DISTRIBUTION OF BORO DERIVED FROM APRIL 2010 IMAGE

As calculated by RS method the total Boro cultivated area in the block is 358.62 hector but it is 400 hector according to the collection from the field.

Weaving and oil milling had been major occupations in the area. The Eden canal from Kanchannagar to Jamalpur was the first irrigation canal in the district. Therefore, rice is the most important crop of the district and in the alluvial plains to the east little else is grown. The rice grown with its numerous varieties can broadly grouped under the three primary classes distinguished from one another by distinct characteristics and there are: The Aus or autumn, the Aman or winter and the Boro or the summer rice. Paddy covers maximum of the gross cropped area. Among commercial crops Jute, Mesta and Sugarcane, potato, oil seeds are cultivated in marginal area. These crops are sailing in the market of Jamalpur town, Bardhaman etc.

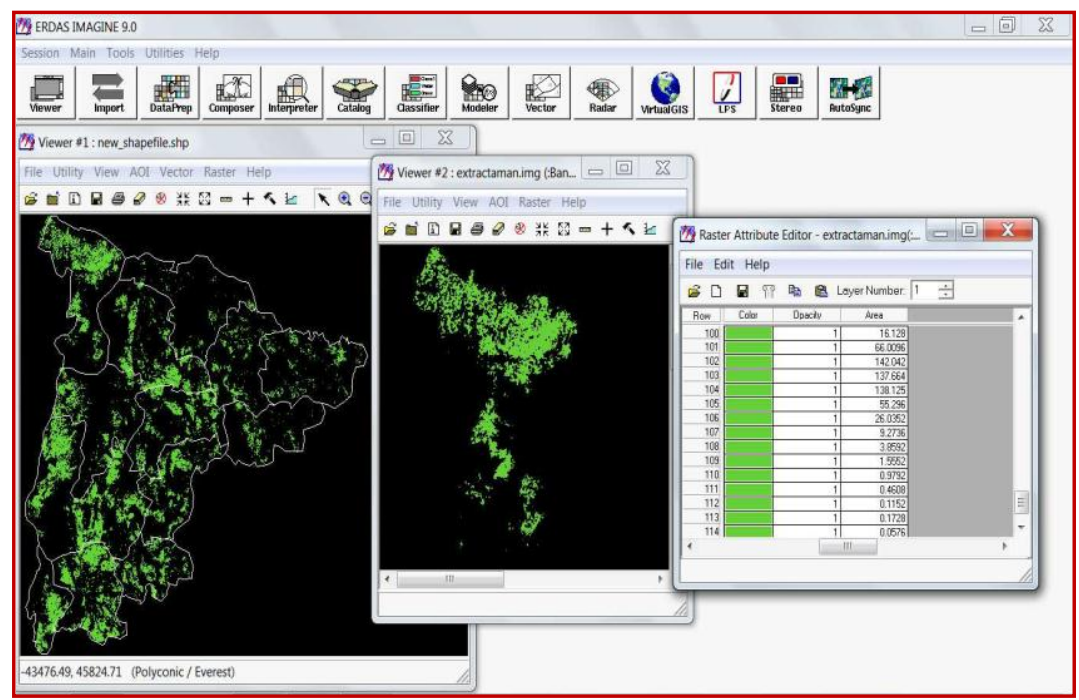

Fig-9: MEASUREMENT OF RICE AREA FROM DIFFERENT GRAM PANCHAYET'S 


\section{Comparing the data between Remote Sensing Analysis and Field collected}

Aman cultivated area

\begin{tabular}{|c|c|c|}
\hline $\begin{array}{c}\text { Gram } \\
\text { Panchayet }\end{array}$ & $\begin{array}{l}\text { Showing area } \\
\text { with the help of } \\
\text { Remote } \\
\text { Sensing data (in } \\
\text { Hector) }\end{array}$ & $\begin{array}{l}\text { Showing } \\
\text { area } \\
\text { collected } \\
\text { from the } \\
\text { field } \\
\text { (in } \\
\text { Hector) }\end{array}$ \\
\hline Berugram & 946.57 & 946.00 \\
\hline Jotsriram & 804.00 & 804.00 \\
\hline Jaragram & $\$ 29.91$ & 834.00 \\
\hline Chakdighi & 745.47 & 745.39 \\
\hline Paratal I & 1009.59 & 1107.00 \\
\hline Paratal II & 942.20 & 942.00 \\
\hline Jamalpur I & 779.00 & 782.00 \\
\hline Jamalpur II & 959.61 & 961.00 \\
\hline Panchra & 955.61 & 955.61 \\
\hline Ajharpur & 1293.00 & 1081.00 \\
\hline Jougram & 839.29 & 994.11 \\
\hline Abujhati I & 65491 & 666.96 \\
\hline Abujhati II & 1082.93 & 1182.93 \\
\hline & $\begin{array}{c}\text { Total- } \\
11842.09\end{array}$ & $\begin{array}{l}\text { Total- } \\
12000.00\end{array}$ \\
\hline & & \\
\hline
\end{tabular}

\section{Aus cultivated area}

\begin{tabular}{|c|c|c|}
\hline $\begin{array}{c}\text { Gram } \\
\text { Panchayet }\end{array}$ & $\begin{array}{l}\text { Showing area } \\
\text { with the help } \\
\text { of Remote } \\
\text { Sensing (in } \\
\text { Hector) }\end{array}$ & $\begin{array}{l}\text { * Showing } \\
\text { area } \\
\text { collected } \\
\text { from the } \\
\text { field } \\
\text { (in } \\
\text { Hector) }\end{array}$ \\
\hline Berugram & 439.16 & 40400 \\
\hline Jotsriram & 659.12 & 703.00 \\
\hline Jaragram & 904.11 & 911.00 \\
\hline Chakdighi & 611.23 & 621.00 \\
\hline Paratal I & 423.19 & 421.00 \\
\hline Paratal II & 673.00 & 679.00 \\
\hline Jamalpur I & 625.99 & 628.00 \\
\hline Jamalpur II & 513.00 & 511.00 \\
\hline Panchra & 696.02 & 647.00 \\
\hline Ajharpur & 913.19 & 907.00 \\
\hline Jougram & 341.84 & 441.00 \\
\hline Abujhati I & 476.25 & 496.00 \\
\hline \multirow[t]{2}{*}{ Abujhati II } & 734.00 & 731.00 \\
\hline & $\begin{array}{c}\text { Total }= \\
8010.10\end{array}$ & $\begin{array}{c}\text { Total }= \\
8100.00\end{array}$ \\
\hline
\end{tabular}

Boro cultivated area

\begin{tabular}{|c|c|c|}
\hline Gram Panchayet & $\begin{array}{l}\text { Showing area } \\
\text { with the help of } \\
\text { Remote Sensing } \\
\text { method (in } \\
\text { Hector) }\end{array}$ & $\begin{array}{l}\text { Showing } \\
\text { area } \\
\text { collected } \\
\text { from the } \\
\text { field } \\
\text { (in } \\
\text { Hectos) }\end{array}$ \\
\hline Benigram & 30.96 & 30.00 \\
\hline Jotsrixam & 23.11 & 2100 \\
\hline Jaragram & 59.30 & 59.00 \\
\hline Chabidighi & 61.23 & 53.00 \\
\hline Pasatal I & 10.96 & 20.00 \\
\hline Paratal II & 10.11 & 28.00 \\
\hline Jamalper I & 26.66 & 33.00 \\
\hline Jaanalpu II & 16.00 & 19.00 \\
\hline Panclua & 17.03 & 24,00 \\
\hline Ajharpur & 27.19 & 33.00 \\
\hline Jongram & 31.99 & 41.00 \\
\hline Abujlati I & 17.08 & 28.00 \\
\hline \multirow[t]{2}{*}{ Abujhati II } & 27.00 & 11.00 \\
\hline & Total $=358.62$ & Total $=400.00$ \\
\hline
\end{tabular}

* Field data collected from ADA office, Jamalpur block

YEAR WISE VARIATIONS OF PADDY CULTIVATED AREA AND PRODUCTION
\begin{tabular}{|c|c|c|c|c|c|c|}
\hline \multirow{2}{*}{ YEAR } & \multicolumn{2}{|c|}{ AUS } & \multicolumn{2}{c|}{ AMAN } & \multicolumn{2}{c|}{ BORO } \\
\cline { 2 - 7 } & Production & $\begin{array}{c}\text { Cultivated area } \\
\text { (hector) }\end{array}$ & Production & $\begin{array}{c}\text { Cultivated area } \\
\text { (hector) }\end{array}$ & Production & $\begin{array}{c}\text { Cultivated area } \\
\text { (hector) }\end{array}$ \\
\hline $2007-08$ & 47600 & 8,300 & 41570 & 14,200 & 46894 & 3,800 \\
\hline $2008-09$ & 47350 & 8,000 & 33533 & 12,000 & 31675 & 5,000 \\
\hline $2009-10$ & 50300 & 8,100 & 42484 & 12,000 & 38979 & 400 \\
\hline $2010-11$ & 40900 & 7,500 & 39618 & 12,300 & 40621 & 1,080 \\
\hline
\end{tabular}

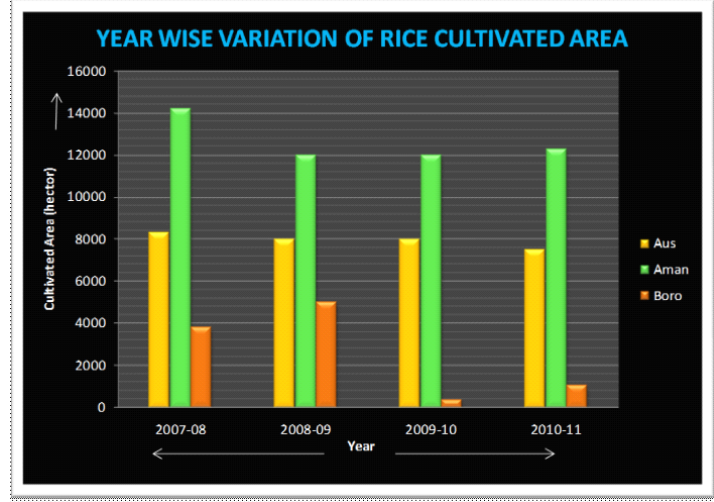

Fig-10: Variation of Rice cultivable area

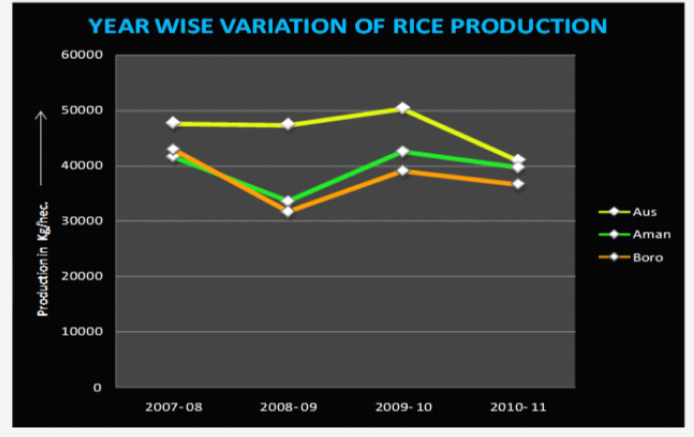

Fig-11: Variation of Rice production

The above variation is of different types of rice cultivated area for last four years. The bar-graph is showing that the rice cultivated area in Jamalpur block is gradually decreasing. In 2007 to 2008, the Aus, Aman and Boro cultivated area were simultaneously 8,300 hector, 14,200 hector and 3,800 hector. But in 2010 to 2011 , the three types of rice cultivated area are gradually decreasing. These are 7,500 hector, 12,300 hector and 1,080 hector.

Likewise, variations of rice production are also decreasing for last four years. In 2007 to 2008 the production of Aus, Aman and Boro rice were simultaneously 47,600 kg/hec, 39,618 kg/hec and 40,621 kg/hec. The bumper year was 2009-10. In that year the three types of rice had been increased than the production of 2007-08. 


\section{Conclusion}

In this study, a comprehensive search on Development of Crop Information System (CIS) for sustainable rice production has been done. This is expected to allow the farm managers and decision makers to carry out more research on what, where, and how best could this be of benefit in various systems/methods of farming for sustainable rice production. Remote sensing can be very efficiently used for precise crop area estimation and provision of crop maps.

On the other hand, available Landsat TM satellite data is suitable to extract rice cultivated field. Both the spatial and the attribute data have been created for the purpose of comprehensive decision making in agricultural practice. The decreasing curve of rice production can be changed the improvement of this area. Government should encourage the development of Crop Information System (CIS) for rice with all crops in the entire block as a whole.

\section{Acknowledgements}

It is my pleasure to introduce to this research work on an important and problematic issue. For modification and completion of this research work, I would like to express my gratitude to my guide Dr. Abhisek Chakrabarty, Assistant Professor, Vidyasagar University. His scholarly opinion about this research topic is as kind as informative.

I am also grateful to Dr. Sandhya Bhadury, Former Deputy Director, NATMO for her initial help.

I am thankful to ADA office, Jamalpur for giving the data. I would like to thanks all the people in the study area. I am also thankful to National Library and specially my department, Remote Sensing \& GIS of Vidyasagar University.

\section{References:}

[1]. FAO (1999), Crop information System, Remote Sensing for Decision-Makers Series, No. 18, Satellite imagery for a Crop Information System, www.ftp.fao.org/doccis/pdf.

[2]. Csornai, G., dr. Dalia, O., Farkasfaly, J., Nádor, G., 1990. Crop Inventory Studies Using Landsat Data on Large Area in Hungary, Applications of Remote Sensing Agriculture, Butterworths, pp. 159-165.

[3]. Remote Sensing Applications, National Remote Sensing Centre (NRSC), Agriculture (Page 1- 20), Sesha Sai MVR, Ramana KV \& Hebbar R.

[4]. Monitoring Of planting paddy rice with complex cropping pattern in the tropical humid climate region using landsat data by S. Uchida, Development Research Division, Japan International Research Center for Agricultural Sciences (JIRCAS)

[5]. Uchida, S., 2007. Monitoring of paddy rice planting with complex cropping pattern using satellite remote sensing data -A case of West Java,Indonesia-, 28th Asian Conference on Remote Sensing, Kuala Lumpur, TS 1.1.

[6]. The Wikipedia-encyclopedia information of Jamalpur area, Burdwan.

[7]. Crop Monitoring by Remote Sensing. G. Csornai, Cs. Wirnhardt, Zs. Suba, P. Somogyi, G. Nádor, L. Martinovich, L. Tikász, A. Kocsis, Gy. Zelei, M. Lelke. 